\title{
Administrative Costs of Taxation in Slovakia
}

\author{
Juraj Nemec - Ladislav Pompura - Vladimír Šagát*
}

\begin{abstract}
:
This article reports an investigation into the administrative costs of the Slovak tax system. By applying methodology used in the Czech Republic, it analyses the administrative costs of taxation in Slovakia between 2004 and 2011. The results show that Slovakia has relatively high costs of tax administration compared to other developed countries, including its neighbours - the V4 countries. We argue that most of the higher relative cost is caused by subjective - speculative factors that will be addressed by ongoing tax system reforms.
\end{abstract}

Key Words: Administrative costs of taxation; Tax administration; Slovakia.

JEL Classification: $\mathrm{H} 20$.

\section{Introduction}

In the theory and practice of Slovak taxation, administrative costs have been considered mostly in connection with questions of efficiency, and with the process of tax harmonization and coordination that is connected with ongoing integration processes. The issue of their measurability and the effort to create a unified methodology, in order to eliminate existing bureaucratic barriers, and the necessity of building a new institutional base for the tax system, did not arise until an OECD study highlighted the higher rate of administrative costs of taxation in transition economies. That study motivated our own study of these issues for the Slovak Republic. It is prefaced by a short summary of current theory and empirical research, and uses a methodology first employed in the Czech Republic.

\section{Theoretical basis and existing investigations}

The first integrated concept of taxation expenses was presented by Smith (2005), whose principles of taxation involved in the Canons of Taxation formed the starting point for the study of the theory and practice of the administrative costs of taxation. Justice, definiteness, convenience and efficiency represent the principles that informed the development of contemporary taxation theory and influenced the development of opinion on the additional expenses of taxation, both in the public and private sectors, which will be the main object of our interest. Efficiency is

* prof. Ing. Juraj Nemec, CSc.; Faculty of Economics, Matej Bel University, Tajovského 10, 97590 Banská Bystrica, Slovakia, <juraj.nemec@umb.sk>.

Ing. Ladislav Pompura, Ph.D.; Executive director; MONAREX, ČSA 24, 97401 Banská Bystrica, Slovakia,<monarex@monarex.sk>.

Ing.Vladimír Šagát, Ph.D.; Department of Finance and Banking, Bankovní institut Praha, zahraničná vysoká škola, Cesta na štadión 7, 97404 Banská Bystrica, Slovakia, <vladimirsagat@centrum.sk>. 
something that is most connected to our theme, it appears to be a constantly present problem in tax administration. The high numbers and low productivity of tax officers has always been an important problem in tax administration. What is important besides economic and fiscal effects in relation to efficiency is the wide scale of noneconomic factors: legislative and legal, organizational and institutional, psychological and sociological. These factors complicate possible solutions, whose difficulties are even greater in the present complex economic and financial period.

Without taxes there would be no costs of taxation. These costs may vary over time and place, and they may be analysed in either of two ways. The first group of authors uses the term administrative costs of taxation only to cover the expenses of the public sector. Sandford refers to them as a subset of the public sector expenses, in which he also includes so called other/sundry costs (Sandford et al., 1989). This is also the starting point for Czech authors like Vítek (2008) or Jílková and Pavel (2006). As another member of this group Vítková deals more closely with the so called cash - flow costs in the government sector, which she classifies as the administrative costs of taxation. She tends to simplify the delimitation of this category, which is also important for further methodological and investigative methods of this problem (Vítková and Vítek, 2012).

The second group of authors, and most notably Stiglitz (1989), divide the costs into two subsets. The first group of administrative costs of taxation are direct costs of the public sector (so called direct administrative costs), and the second group are indirect expenses of the private sector (incurred expenses of taxation). Authors adhering to this theory of administrative costs in our conditions are for example Hamerníková and Kubátova (2000), Medved' (2004), and Peková (2002). A polemic issue in this respect is the so called alternative administrative costs, including lost interest and expenses connected with psychological harm. Authors who follow the second group of views declare incurred expenses to be administrative, and consider the above mentioned alternative expenses to be part of them. In our point of view this idea is not acceptable, and this is one of the reasons we incline rather to the first group of authors.

The risks of misinterpretation for other reasons have been pointed out, in particular by Vítek (2008). He refers to the private sector expenses and to the incurred expenses of taxation. According to them, taxpayers must bear incurred expenses of taxation that originate from the existence of the taxation system. So the incurred expenses of taxation are equal to the amount of expenses which the taxpayers would not have to bear if the tax system did not exist. Both authors also use this argument in the concept of the social costs of taxation referred to by Pudil et al (2004). The above mentioned factors also strongly influenced investigations in this domain, which focused mainly on the incurred expenses of taxation. Čižmárik 
(2013) documented a coherent overview of research undertaken in this area, and described three of the main spheres of problems:

- The low degree of comparability among studies;

- The inadequate consistency of methods;

- Considerable variations in the geographical and other conditions of research.

In American research Vaillancourt (1987) used a questionnaire research under comparable conditions. European investigations were mostly accomplished in the 1960's and 1970's, and dealt on a bigger scale with methodological and conceptual problems, defining the key concepts and links. Sandford $(1989,1995)$ in the United Kingdom and Ireland, for the first time compared the results of existing works and outputs on the basis of comparable methods. Relating to the model of fiscal federalism, an interesting study for the USA is Slemrod and Sorum (1984), who study both federal and state taxes, including their administrative costs.

Especially valuable for the present integrative tax policy and practice in the EU are the results of the so called the 3rd wave of research. Experience from Sweden (Malmer, 1995) is also interesting for our research, showing verifiable outputs, including administrative costs, as a result of implemented tax reforms. Hasseline and Hansford (2002) for the United Kingdom analyse Value Added Tax problems including increased expenses in companies with higher turnover, and the increasing complexity of the tax system. In this context, Blaufus, Eichfelder and Hundsdoerfer (2011) published results for Germany on the analysis of time requirements, the incomes of individuals and society, and the use of external services.

There are many other studies about this topic in the world (like Alm, 1996, Evans, 2003, Chittenden et al, 2005. Lignier and Evans, 2012, Mirrlees, 1971, Susila and Pope, 2012, Tran Nam et al, 2000) but also in our region (like Bayer, 2013, Klun 2004, Klun and Blazic, 2005, Pavel and Vítek, 2010, 2012, Tepperová and Kubantová, 2013).

\section{Implemented methods}

As we have argued administrative costs are connected to the efficiency of tax systems. The core of our research was an investigation in Slovakia, where we proceeded from the assumption that the tax administration's sole goal is to minimize the expenses connected with levying, collecting and administering a given volume of taxes. While measuring the administrative costs of taxation, one should take into consideration not only the direct expenditures from public budgets but also selected indirect public sector expenditures connected with tax collection. These costs can be characterised as total expenses of the tax system. 
Nemec, J. - Pompura. L. - Šagát, V.: Administrative Costs of Taxation in Slovakia.

In our research we chose to quantify the relation between tax revenue and operational expenses, to facilitate comparison with other studies, especially with results from the Czech Republic (Pudil et al., 2004), (Vítek, 2008), (Vítková, 2008), (Vítková, Vítek, 2012). Thus our contribution is not a novel methodology, but is producing comparable Slovak results using existing methods.

Like the Czech tax administration, the Slovak tax administration does not use project financing or budgeting ("full cost accounting"), and so it is impossible to easily identify the expenses connected to the collection of specific taxes. Our calculations are based on the method of the so called rated "convertible" employee. This sorts employees with respect to the specification of their activities, and constructs the conversion rate coefficients needed for dividing total organizational costs into those connected with tax collection, and the remainder (Pudil et al., 2004). We applied this method to the Slovak Republic, where until 2012 there was a comparable structure of tax administration positions. The specifics of our methodology allow a conversion for the particular types of tax characteristic of the Slovak system.

\subsection{Calculating number of employees involved in tax collection and of administrative costs of taxation}

With respect to the facts mentioned above, we adapted the methods of the Czech tax administration to the Slovak situation as follows: the total number of employees in the Slovak Tax Administration according to comparable positions between 2004 and 2011 is shown in Table 1.

\section{Tab. 1: Employee structure of the Tax Directorate of the Slovak Republic 2004-2011}

\begin{tabular}{|c|c|c|c|c|c|c|c|c|}
\hline \multirow{2}{*}{ Position } & \multicolumn{8}{|c|}{ Number of Employees } \\
\hline & 2004 & 2005 & 2006 & 2007 & 2008 & 2009 & 2010 & 2011 \\
\hline Director & 359,0 & 318,0 & 310,0 & 310,0 & 314,0 & 305,0 & 302,0 & 301,0 \\
\hline Inspector & 1746,0 & 1752,0 & 1785,0 & 1647,5 & 1616,5 & 1570,0 & 1563,3 & 1581,5 \\
\hline Manager & 1910,0 & 1863,0 & 1846,0 & 1765,8 & 1750,2 & 1749,7 & 1741,4 & 1738,2 \\
\hline Executive & 276,0 & 290,0 & 200,0 & 282,7 & 277,5 & 274,5 & 275,5 & 276,2 \\
\hline State Supervisor & 239,0 & 219,0 & 173,0 & 160,0 & 157,0 & 151,0 & 144,0 & 135,4 \\
\hline Registrar & 216,0 & 231,0 & 236,0 & 232,7 & 234,5 & 230,1 & 234,8 & 238,9 \\
\hline Administrator & 59,0 & 60,0 & 61,0 & 65,1 & 65,9 & 64,1 & 60,4 & 62,3 \\
\hline Others & 1292,0 & 1335,0 & 1313,0 & 1307,2 & 1309,4 & 1341,6 & 1305,6 & 1298,4 \\
\hline Total $\mathrm{TE}_{\mathrm{to}}$ & 6097,0 & 6068,0 & 5924,0 & 5771,0 & 5725,0 & 5686,0 & 5627,0 & 5612,0 \\
\hline
\end{tabular}

Source: Own evaluation of data from annual reports of the Slovak Tax Directorate.

Table 1 includes employees involved directly in tax collection, employees involved directly in non-tax-related activities, indirect personnel in taxrelated activities and other indirect personnel, not classified as employees in the Czech tax administration, but structured according to the position structure in the Slovak Republic. We classified all employees of the Slovak tax administration into 
European Financial and Accounting Journal, 2015, vol. 10, no. 2, pp. 51-61.

those directly engaged in tax collection (see Table 1 in annex), and then calculated the weighted number of indirect personnel to be added (see Tables 2 and 3 in annex). Using the recalculated employee estimates, and again following the Czech methodology, the total administrative costs of the Slovak tax system were allocated according to the main tax types (see Table 2).

Tab. 2: Total administrative costs of taxation in Slovakia according to main types of taxes (2004-2008 in thousands SKK, 2009-2011 in thousands $€$ )

\begin{tabular}{|c|c|c|c|c|c|c|c|c|}
\hline Years & 2004 & 2005 & 2006 & 2007 & 2008 & 2009 & 2010 & 2011 \\
\hline $\begin{array}{l}\text { Income tax of } \\
\text { individuals - } \\
\text { Employees }\end{array}$ & 353874 & 596514 & $7019 i$ & 683474 & 733550 & 23826 & 25979 & 27161 \\
\hline $\begin{array}{l}\text { Income tax of } \\
\text { individuals - } \\
\text { Entrepreneurs }\end{array}$ & 516308 & 391828 & 429482 & 415387 & 428940 & 14930 & 15137 & 15801 \\
\hline $\begin{array}{l}\text { Corporate } \\
\text { income tax }\end{array}$ & 887585 & 693009 & 731600 & 727664 & 795716 & 25462 & 27160 & 28273 \\
\hline $\begin{array}{l}\text { Income tax - } \\
\text { lump sum form }\end{array}$ & 75416 & 93571 & 97744 & 67758 & 90140 & 2513 & 3114 & 3228 \\
\hline Property tax & 14503 & 17545 & 5924 & 11784 & 6217 & 102 & 107 & 111 \\
\hline VAT & 992007 & 1067292 & 938936 & 992805 & 1007788 & 33950 & 34137 & 35064 \\
\hline Road Tax & 52211 & 55558 & 50353 & 41244 & 40407 & 1227 & 1503 & 1447 \\
\hline Total & 2900606 & 2924089 & 2961942 & 2946008 & 3108264 & 102215 & 107350 & 111085 \\
\hline
\end{tabular}

Source: Own calculations from annual reports of the Tax Directorate of the Slovak Republic.

\section{Results and their discussion}

To allow for comparative analysis the absolute data from Table 2 is presented in relative form in Table 3 . The results suggest that the main problem is connected to the income tax paid by self-employed entrepreneurs. The costs to collect this tax are more or less stabilised (2004 can be data error), however revenues from this tax step by step decrease resulting into the rise in the relative costs of collecting this tax, especially in 2010 and 2011 was caused by its particularly low collection revenues in the Great Recession. 
Nemec, J. - Pompura. L. - Šagát, V.: Administrative Costs of Taxation in Slovakia.

Tab. 3: Administrative costs as a percentage of tax revenues, by specified tax, 2004-2010

\begin{tabular}{lrrrrrrrr}
\hline & & \multicolumn{1}{c}{$\%$} & & & & \\
& $\mathbf{2 0 0 4}$ & $\mathbf{2 0 0 5}$ & $\mathbf{2 0 0 6}$ & $\mathbf{2 0 0 7}$ & $\mathbf{2 0 0 8}$ & $\mathbf{2 0 0 9}$ & $\mathbf{2 0 1 0}$ & $\mathbf{2 0 1 1}$ \\
\hline $\begin{array}{l}\text { Income tax of individuals } \\
\text { - Employees }\end{array}$ & $\mathrm{x}$ & 1,77 & 1,96 & 1,64 & 1,48 & 1,62 & 1,81 & 1,65 \\
Income tax of individuals & 1,98 & 5,86 & 7,64 & 7,92 & 7,04 & 7,92 & 30,76 & 25,51 \\
- Entrepreneurs & 2,99 & 1,62 & 1,52 & 1,37 & 1,23 & 1,18 & 2,11 & 1,65 \\
Corporate income tax & 1,33 & 2,43 & 2,01 & 1,19 & 1,45 & 1,61 & 2,04 & 2,25 \\
Income tax - lump sum & 0,53 & 1,82 & 1,81 & 19,32 & 14,80 & 14,61 & 13,42 & 31,80 \\
form & 3,63 & 1,32 & 1,28 & 1,41 & 1,47 & 1,52 & 1,52 & 1,59 \\
Property tax & 4,10 & 1,97 & 1,72 & 1,16 & 1,52 & 1,00 & 1,26 & 1,12 \\
VAT & & & & & & &
\end{tabular}

Source: Own evaluation of data.

To assess our results, first it is needed to compare them with the above mentioned Czech research, obtained using the same methodology. The results as shown in the Table 4 indicate that Czech tax administration is significantly cheaper than Slovak tax administration. We argue that these differences are real, because they are too large to be caused by minor methodological disparities, such as small variations in the classification of tax office staff, or the quality of input data.

\section{Tab. 4: Comparison of the administrative costs of taxation in the Czech} Republic and Slovakia for main taxes

\begin{tabular}{|c|c|c|c|c|c|c|}
\hline & 2001 & 2002 & 2003 & 2004 & 2005 & Slovakia \\
\hline $\begin{array}{l}\text { Income tax of individuals } \\
\text { - Employees }\end{array}$ & 1,33 & 1,15 & 1,18 & 1,17 & 1,15 & $\begin{array}{l}\text { Income tax of individuals } \\
\text { - Employees: } 1,48-1,96 \\
\text { Income tax of individuals } \\
\text { Entrepreneurs: } \\
1,98-30,76\end{array}$ \\
\hline $\begin{array}{l}\text { Corporate income tax } \\
\text { VAT } \\
\text { Total }\end{array}$ & $\begin{array}{l}0,79 \\
2,26 \\
1,40 \\
\end{array}$ & $\begin{array}{l}0,66 \\
2,21 \\
1,38 \\
\end{array}$ & $\begin{array}{l}0,67 \\
2,29 \\
1,40 \\
\end{array}$ & $\begin{array}{l}0,66 \\
1,65 \\
1,30 \\
\end{array}$ & $\begin{array}{l}0,59 \\
0,78 \\
1,20 \\
\end{array}$ & $\begin{array}{l}1,18-2,99 \\
1,28-3,63 \\
1,86-3,01 \\
\end{array}$ \\
\hline
\end{tabular}

Source: (Pudil et al., 2004), own calculations.

In this situation the obvious question is to ask why Slovakia is significantly more expensive, especially when the large scale 2004 tax reform focused on simplifying the tax system. Our current research provides no objective explanation. However, Table 5 suggests that economies of scale can be ruled out, there are no obvious negative relations between country size and relative administrative costs, for given levels of taxation. 


\section{Tab. 5: Taxation level and administrative costs of taxation: selected countries}

\begin{tabular}{|c|c|c|c|c|}
\hline \multirow{2}{*}{$\begin{array}{c}\text { Countries according } \\
\text { to the their } \\
\text { administrative costs } \\
\text { of taxation }(\%)\end{array}$} & \multicolumn{4}{|c|}{ Countries according to their tax revenues to GDP } \\
\hline & $<20 \%$ & $20-30 \%$ & $30-40 \%$ & Over $40 \%$ \\
\hline$-0,60$ & & USA & & Sweden \\
\hline $0,61-0,80$ & & Korea & $\begin{array}{l}\text { Ireland, Spain, } \\
\text { New Zealand }\end{array}$ & $\begin{array}{l}\text { Austria, } \\
\text { Denmark, } \\
\text { Finland, } \\
\text { Germany, } \\
\text { Norway }\end{array}$ \\
\hline $0,81-1,00$ & Mexico & Turkey & & France \\
\hline $1,01-1,20$ & & & $\begin{array}{l}\text { Hungary, } \\
\text { Netherlands, } \\
\text { UK }\end{array}$ & Luxembourg \\
\hline $1,21-1,40$ & & & Canada & $\begin{array}{l}\text { Belgium, } \\
\text { Czech } \\
\text { Republic }\end{array}$ \\
\hline $1,40+$ & & Japan & $\begin{array}{l}\text { Poland, } \\
\text { Portugal, } \\
\text { Slovakia }\end{array}$ & \\
\hline
\end{tabular}

Source: OECD, 2011.

Even if there is no conclusive explanation for such relatively high Slovak tax administration costs, weaker evidence might suggest ways to reduce costs.

One area suggests itself. Despite all previous reforms, collecting income tax from the self employed is rather expensive both for the state (administrative costs calculated by us) and also for the self-employed. Our calculations confirm high administrative costs. Cizmarik (2013) estimated the compliance costs of this type of tax as being as high as $200 \%$ in the most difficult years. This needs an effective response to reduce compliance costs, yet the current centre-left government is working in the opposite direction.

Excessively high tax administrative costs suggest excessively low technical efficiency in the tax administration. Yet from 2012 the large scale tax system reform (UNITAS) was undertaken by the Slovak government. Its main goals are to improve the flow and a usage of information as well as to merge the collection of all taxes and social contributions under one administration. In the previous system evaluated by this text, four types of factors were involved in tax collection - Tax office, Social Insurance Company, four health insurance companies and selfgovernments. From 2015 onwards new data may show whether such a merger delivers. 
Nemec, J. - Pompura. L. - Šagát, V.: Administrative Costs of Taxation in Slovakia.

\section{Conclusions}

The goal of this research was to calculate the administrative costs of taxation in the Slovak Republic. To obtain comparative results we have used the same methodology as previous research in the Czech Republic. Unfortunately, our (relatively very reliable) results indicate that tax administration in Slovakia is rather expensive and this situation cannot be effectively explained by objective factors.

On the basis of our findings we can propose two directions for possible improvements. The first involves further simplification of the Slovak tax system, but as of today the government is not going this way. The second option is a significant improvement in the technical efficiency of the tax administration in the Slovak Republic. Reform UNITAS, which started in 2012, is expected to achieve this goal and we will be able to assess its results within a few years. The goal should be the reduction of Slovak administrative costs of taxation at least to the average level of OECD countries. Changes should be based on existing knowledge derived from studies focusing on the sphere in question, on issues like the size of tax offices, time-consuming agendas, the functional positions of employees, the structure of expenditures, the quality of tax control and the qualifications and motivation of all staff. One of the specific steps forward would be creating a "customer friendly" tax administration system which will provide tax payers with better information and increase their trust in the tax system.

\section{References}

Alm, J., 1996. What is an "Optimal" Tax System? National tax Journal 1, 117133.

Bayer, O., 2013. Research of Estimates of Tax Revenue: An Overview. European Financial and Accounting Journal 3, 59-73.

Blaufus, K., Eichfelder, S., Hurdsdoerfer J., (2011). The Hidden Burden of the Income tax. Compliance Costs of German Individuals. Freie Universität Berlin, School of Business and Economics, Working paper 6,1-40.

Čižmárik, P., 2013. Vyvolané náklady zdanenia. Dissertation thesis (PhD.). Masarykova univerzita Brno.

Evans, C., 2003. Studying the Studies: An overview of recent research into taxation operating costs. eJournal of Tax Research 1, 64-82.

Hamerníková, B., Kubátová, K., 2000. Veřejné finance, Praha: Eurolex Bohemia.

Hasseldine, J., Hansford, A., 2002. The Compliance Burden of the VAT. Further Evidence from the UK. Australian Tax Forum 4, 369-388. 
Chittenden, F., Kauser, S., Poutziouris, P., 2005. PAYE-NIC compliance costs: empirical evidence from the UK SME economy. International Small Business Journal 6, 635-656.

Jílková, J., Pavel, J., 2006. Hodnocení efektivnosti veřejných výdajů na ochranu životního prostředí. Praha: IREAS.

Klun, M., 2004. Compliance costs for personal income tax in a transition country: the case of Slovenia. Fiscal Studies 1, 93-104.

Klun, M., Blazic, H., 2005. Tax compliance costs for companies in Slovenia and Croatia. Finanzarchiv 3, 418-437.

Lignier, P., Evans, C., 2012. The Rise and Rise of Tax Compliance Costs for the Small Business Sector in Australia. Australian Tax Forum 3, 615-672.

Malmer, H., 1995. The Swedish Tax Reform in 1990-91 and Tax Compliance Costs in Sweden. In: Sandford, 226-262.

Mirrlees, J. A., 1971. An Exploration in the Theory of Optimum Income Taxation. The Review of Economic Studies 2, 175-208.

Medved', J., Nemec, J., 2004. Mikroekonomické východiská verejných financií. Bratislava: Sprint.

OECD, 2011. Tax Administration in OECD and Selected non-OECD countries: Comparative Information Series (2010). Paris: Organization for Economic Cooperation and Development.

Pavel, J., Vítek, L., 2010. Environmental Tax Reform: Administrative and Compliance Costs of Energy Taxes in the Czech Republic. In Soares, C. D. et al. (eds.). Critical Issues in Environmental Taxation. International and Comparative Perspectives. Oxford: Oxford University Press VIII, 76-88.

Pavel, J., Vítek, L., 2012. Transaction Costs of Environmental Taxation: the Administrative Burden. In Milne, J. E. - Andersen, M. S. (eds.). Handbook of Research on Environmental Taxation. Cheltenham: Edward Elgar, 273-282. ISBN 978-1-84844-997-8.

Peková, J., 2002. Veřejné finance - úvod do problematiky. Praha: ASPI.

Pudil, P., Vybíhal, V., Vítek, L., Pavel, J. et al., 2004. Zdanění a efektivnost. Praha: Eurolex Bohemia.

Sandford,C. et al. 1989. Administrative and Compliance Costs of Taxation. London: Fiscal Publications.

Sandford, C. et al. 1995. Tax Compliance Costs. Measurment and policy. Bath: Fiscal Publications.

Slemrod, J. R., Sorum, N., 1984. The Compliance Cost of the U.S. Individual Income Tax System. The National Tax Journal 4, 461-474. 
Nemec, J. - Pompura. L. - Šagát, V.: Administrative Costs of Taxation in Slovakia.

Smith, A., 2005. Inquiry into the Nature and Causes of the Wealth of Nations. Philadelphia:The Pensylvania State University.

Stiglitz, J. E., 1989. Economics of the Public Sector. New York: Norton.

Susila, B., Pope, J., 2012. The Tax Compliance Costs of Large Corporate Taxpayers in Indonesia. Australian Tax Forum 27, 719-772.

Solilová, V., Nerudová, D., 2013. Transfer pricing: General Model for Tax Planning. Ekonomický časopis 6, 597-617.

Tepperová, J., Kubantová, K., 2013. Omezení a možnosti jednoho inkasního místa v České republice. Český finanční a účetní časopis 1, 61-76.

Tran-Nam, B., Evans, C., Walpole, M., Ritchie, K., 2000. Tax Compliance Costs: Research Methodology and Empirical Evidence from Australia. National Tax Journal 2, 229-252.

Vaillancourt, F., 1987. The Compliance Cost of Taxes on Business and Individuals: A Review of the Evidence. Public Finance 3, 395-414.

Vítek, L., 2008. Ekonomická analýza zdanění př́ijmů. 1. vydání. Praha: IREAS.

Vítková, J., Vítek, L., 2012. Spoločenské vyvolané náklady zdanění. Acta Oeconomica Pragensia 1, 15-30. 


\section{Appendix}

Tab. 1: Job categories of employees involved directly in Slovak tax collection 2004 -2011

\begin{tabular}{|c|c|c|c|c|c|c|c|c|}
\hline \multirow{2}{*}{ Position } & \multicolumn{8}{|c|}{ Number of Employees } \\
\hline & 2004 & 2005 & 2006 & 2007 & 2008 & 2009 & 2010 & 2011 \\
\hline Inspector & 1746,0 & 1752,0 & 1785,0 & 1647,5 & 1616,5 & 1570,0 & 1563,3 & 1561,5 \\
\hline Manager & 1910,0 & 1863,0 & 1846,0 & 1765,8 & 1750,2 & 1749,7 & 1741,4 & 1738,2 \\
\hline Executive & 276,0 & 290,0 & 200,0 & 282,7 & 277,5 & 274,5 & 275,5 & 276,2 \\
\hline State Supervisor & 239,0 & 219,0 & 173,0 & 160,0 & 157,0 & 151,0 & 144,0 & 135,4 \\
\hline Registrar & 216,0 & 231,0 & 236,0 & 232,7 & 234,5 & 230,1 & 234,8 & 238,9 \\
\hline Administrator & 59,0 & 60,0 & 61,0 & 65,1 & 65,9 & 64,1 & 60,4 & 62,3 \\
\hline Total & 4446,0 & 4415,0 & 4301,0 & 4153,8 & 4101,6 & 4039,4 & 4019,4 & 4012,5 \\
\hline
\end{tabular}

Source: Own calculations from annual reports of the Tax Directorate of the Slovak Republic.

Tab. 2: Ratio of direct employees to total employees involved in tax collection for the Slovak Tax Administration 2004-2011 (C1)

\begin{tabular}{lrrrrrrrr}
\hline Years & $\mathbf{2 0 0 4}$ & $\mathbf{2 0 0 5}$ & $\mathbf{2 0 0 6}$ & $\mathbf{2 0 0 7}$ & $\mathbf{2 0 0 8}$ & $\mathbf{2 0 0 9}$ & $\mathbf{2 0 1 0}$ & $\mathbf{2 0 1 1}$ \\
\hline $\begin{array}{l}\text { Directly } \\
\text { involved }\end{array}$ & 4446,0 & 4415,0 & 4301,0 & 4153,8 & 4101,6 & 4039,4 & 4019,4 & 4012,5 \\
employees & & & & & & & & \\
Total employees & 6097,0 & 6068,0 & 5924,0 & 5771,0 & 5725,0 & 5686.0 & 5627,0 & 5612,0 \\
Coefficient C1 & 0,729 & 0,728 & 0,726 & 0,720 & 0,716 & 0,710 & 0,714 & 0,715 \\
\hline
\end{tabular}

Source: Own calculations from annual reports of the Tax Directorate of the Slovak Republic.

Tab. 3: Estimates of the total number of employees involved in Slovak tax collection 2004-2011

\begin{tabular}{lrrrrrrrr}
\hline Years & $\mathbf{2 0 0 4}$ & $\mathbf{2 0 0 5}$ & $\mathbf{2 0 0 6}$ & $\mathbf{2 0 0 7}$ & $\mathbf{2 0 0 8}$ & $\mathbf{2 0 0 9}$ & $\mathbf{2 0 1 0}$ & \multicolumn{1}{c}{$\mathbf{2 0 1 1}$} \\
\hline Direct employees & 4446,0 & 4415,0 & 4301,0 & 4153,8 & 4101,6 & 4039,4 & 4019,4 & 4012,5 \\
Coefficient C1 & 0,729 & 0,728 & 0,726 & 0,720 & 0,716 & 0,710 & 0,714 & 0,715 \\
$\begin{array}{l}\text { Recalculated } \\
\text { number of non } \\
\text { directly involved }\end{array}$ & 134,14 & 131,77 & 132,86 & 129,6 & 129,6 & 127,8 & 127,09 & 127,27 \\
$\begin{array}{l}\text { employees } \\
\text { Total }\end{array}$ & & & & & & & & \\
\hline
\end{tabular}

Source: Own calculations from annual reports of the Tax Directorate of the Slovak Republic. 
